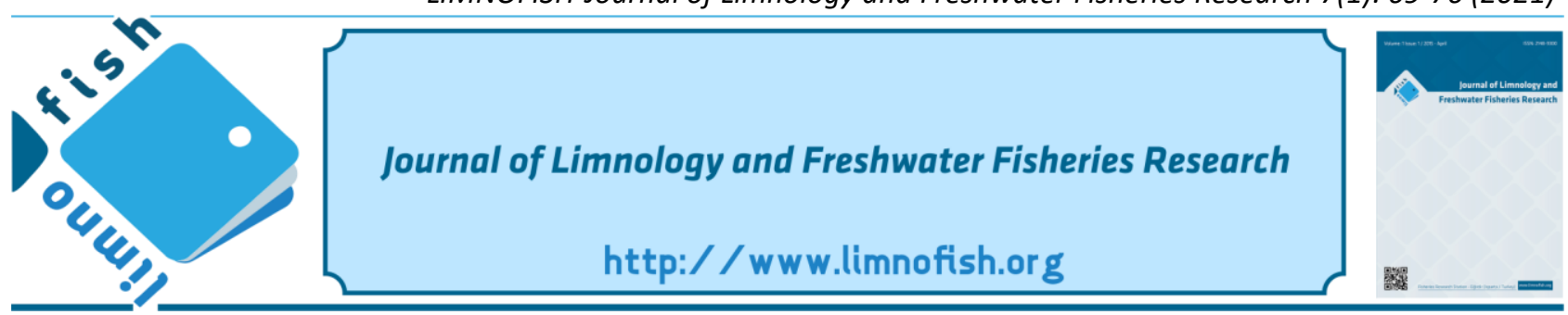

\title{
Determination of Some Biochemical Parameters Changes in Gammarus pulex Exposed to Cadmium at Different Temperature and Different Concentration
}

\author{
Osman SERDAR $^{1^{*}}$ (๑), Rahmi AYDIN ${ }^{1}$ (D), Metin ÇALTA ${ }^{2}$ (D) \\ ${ }^{1}$ Munzur University, Fisheries Faculty, TR62000 Tunceli, Turkey \\ ${ }^{2}$ Frrat University, Fisheries Faculty, TR23000 Elazı̆g, Turkey
}

\section{A B STRACT}

In this study, the oxidative stress effects of cadmium $(\mathrm{Cd})$ toxicity depending on water temperature were investigated on Gammarus pulex. The test organism individuals were exposed to sublethal concentrations for 96 hours at certain rates $(\mathrm{C} 1 ; 1 / 10, \mathrm{C} 2 ; 1 / 20$ and $\mathrm{C} 3 ; 1 / 40)$ of LC50 values of $\mathrm{Cd}$ for each temperature $\left(10,14,18^{\circ} \mathrm{C}\right)$. Malondialdehyde (MDA) level, glutathione peroxidase (GPx), and catalase (CAT) enzyme activities were investigated at the temperatures determined in G. pulex exposed to Cd. With the increasing temperature, the MDA level and CAT enzyme activity increased while GPx enzyme activities decreased. The results of this study revealed that the biochemical response caused by $\mathrm{Cd}$ on G. pulex had statistically significant differences $(\mathrm{p}<0.05)$ with temperature. In this study, the use of MDA levels with CAT and GPx-related enzymes, Cd exposure, toxicity, and temperature change as biomarkers for risk assessment may be useful.

Keywords: Gammarus pulex, cadmium, malondialdehyde, glutathione peroxidase, catalase

\section{ARTICLE INFO}

\section{RESEARCH ARTICLE}

Received : 04.06.2020

Revised : 30.10 .2020

Accepted : $: 30.10 .2020$

Published :29.04.2021

DOI:10.17216/LimnoFish.748137

\section{* CORRESPONDING AUTHOR}

oserdar@munzur.edu.tr

Phone : +90 5056959334

Farklı Sicaklık ve Farklı Konsantrasyonlarda Kadmiyuma Maruz Bırakılan Gammarus pulex'te Bazı Biyokimyasal Parametrelerin Değişikliklerinin Belirlenmesi

Öz: Bu çalışmada Gammarus pulex üzerinde kadmiyum $(\mathrm{Cd})$ toksisitesinin su sıcaklığına bağlı olarak oksidatif stres etkileri araştııılmıştır. Test organizması bireyleri, her sıcaklık $\left(10,14,18{ }^{\circ} \mathrm{C}\right)$ için belirli oranlarda $(\mathrm{C} 1 ; 1 / 10, \mathrm{C} 2 ; 1 / 20$ ve $\mathrm{C} 3 ; 1 / 40) \mathrm{LC} 50$ değerlerinin 96 saat boyunca subletal konsantrasyonlara maruz bırakıldı. Cd'ye maruz kalan G. pulex'te belirlenen sicaklıklarda malondialdehid (MDA) seviyesi, glutatyon peroksidaz (GPx) ve katalaz (CAT) enzim aktiviteleri araştırıldı. Sıcaklık arttıkça MDA seviyesi ve CAT enzim aktivitesi artarken GPx enzim aktiviteleri azaldı. Bu çalışmanın sonuçlarına göre, G. pulex üzerinde Cd'nin neden olduğu biyokimyasal yanıtın sıcaklık ile istatistiksel olarak anlamlı farklılıklara $(\mathrm{p}<0,05)$ sahip olduğu belirlenmiştir. Bu çalışmada, risk değerlendirmesi için biyobelirteç olarak MDA seviyelerinin CAT ve GPx ile ilişkili enzimler, Cd maruziyeti, toksisite ve sıcaklık değişimi ile kullanılması yararlı olabilir.

Anahtar kelimeler: Gammarus pulex, kadmiyum, malondialdehit, glutatyon peroksidaz, katalaz

How to Cite

Serdar O, Aydın R, Çalta M. 2021. Determination of Some Biochemical Parameters Changes in Gammarus pulex Exposed to Cadmium at Different Temperature and Different Concentration, LimnoFish. 7(1): 69-76. doi: 10.17216/LimnoFish.748137

\section{Introduction}

Aquatic environments are widely accepted today as a simple and inexpensive disposal option that is considered an ideal discharge area for most waste. This has led to increased ecological poisoning due to the bioaccumulation of toxic chemicals and some long-standing pollutants, including developed countries (Taylan and Özkoç 2007). Increasing industrial, urban, and agricultural developments increase the environmental problems of today and these environmental problems have a negative synergy effect with living things along with global warming. Heavy metals, which make up the majority of industrial pollutants, can enter into the structures of aquatic organisms through wastewater (Bat et al. 2000). One of the most important sources of ecosystem health is heavy metal pollution and it poses stress, threat, and a great risk to organisms in aquatic ecosystems (Del Valls et al. 1998). When a metal enters the biological system of any organism, it can damage the vital functions of that organism $(\mathrm{Hu}$ 2000; Kayhan 2006). Increasing concentrations of 
heavy metals in aquatic environments are taken up by aquatic organisms and transported to upper trophic levels via food chains. Examination of heavy metal accumulation in living organisms living in the water environment is important in determining the species susceptible to heavy metals as well as in determining the structural and functional disorders that occur in the organism (Kayhan 2006).

Cadmium (Cd), one of the heavy metals with toxic effects in environmental pollutants, is very harmful to aquatic organisms even at low concentrations (Katalay and Parlak 2002; Asri et al. 2007). Cd is the heaviest metal element with the highest water solubility. For this reason, the broadcast speed is high. It is also not one of the necessary elements of human life. Because of its solubility property, it is released into biological systems by plant and aquatic organisms in the form of $\mathrm{Cd}^{+2}$ and has accumulation properties (Duffus 1980).

An indirect mechanism for the free radical production caused by $\mathrm{Cd}$ is suggested. $\mathrm{Cd}$ increases the amount of non-bound forms of these metals by taking the place of zinc $(\mathrm{Zn})$, calcium $(\mathrm{Ca})$, copper $(\mathrm{Cu})$, and iron $(\mathrm{Fe})$ in metalloenzymes. It binds to thiol groups of free radical scavengers such as glutathione (GSH) and inhibits antioxidant enzymes such as catalase (CAT), superoxide dismutase (SOD), and glutathione peroxidase (GPx). Although it is Fenton metal, it is thought that it causes the production of superoxide and nitric oxide, and many other free radicals and thus leads to peroxidation, DNA damage, and protein oxidation of cell membrane structures (Brzóska and MoniuszkoJakoniuk 2001; Waisberg et al. 2003; Bertin and Averbeck 2006).

One of the methods of determining pollution in the aquatic environment is to determine the levels of the organisms living in the environment that are affected by this pollution. The evaluation of biological markers as an early warning of adverse changes and damage has been shown as a suitable tool for Gammarus pulex (Dat et al. 2000; Achary et al. 2008; Yildirim et al. 2018; Serdar 2019). Reactive oxygen species (ROS) suppress the antioxidant system, inducing oxidative stress, lipid peroxidation, and oxidation of proteins during metabolism (Almroth et al. 2008; Tatar et al. 2018; Cimen et al. 2020). There is an important balance between the production of ROS and the removal of antioxidant defense systems by organisms. ROS is cleared by antioxidant enzymes and non-enzymatic antioxidants (Hermes-Lima 2004; Halliwell and Gutteridge 2007; Serdar et al. 2018). Lipid peroxidation is chain reaction in which oxidants break down membrane phospholipids with polyunsaturated fatty acids. Lipid peroxidation causes damage to bio-membranes, which can lead to significant consequences for living organisms (Hermes-Lima 2004; Jemec et al. 2012; Serdar et al. 2018).

This study was designed to determine the effect of pollution in the water environment on the organism in the water together with the global temperature with the development of the industrial sector. Therefore, it is aimed to experimentally determine the effect of sublethal $\mathrm{Cd}$ concentrations on G. pulex, a water organism, at different temperature levels.

\section{Materials and Methods \\ Test Organisms}

The test organism G. pulex used in the study was collected from the source part of the tributaries of the Munzur River of Tunceli province, with hand nets from the areas that are virgin in terms of domestic and industrial pollution. Before the experimental study, organisms were adapted at 10,14 , and $18 \pm 0.5^{\circ} \mathrm{C}$, respectively, at the test temperature. Ambient lighting 12:12 bright: dark it is set to be climate controlled in its cycle. In this process, the test organisms were fed with rotten willow leaves. Organisms were checked daily.

\section{Acute Toxicity $\left(\mathrm{LC}_{50}\right)$}

Serdar et al. (2019a) determined their Cd LC50 values in G. pulex at 10,14 , and $18^{\circ} \mathrm{C}$. LC50 values for 10,14 , and $18^{\circ} \mathrm{C}$ temperatures are $51.79 \pm 1.2 \mu \mathrm{g}$ $\mathrm{L}^{-1} \mathrm{Cd}, 47.67 \pm 0.6 \mu \mathrm{g} \mathrm{L}^{-1} \mathrm{Cd}$, and $33.93 \pm 0.6 \mu \mathrm{g} \mathrm{L}^{-1}$ $\mathrm{Cd}$, respectively. LC50 values used in this study Serdar et al. (2019a)'s taken from the work they have done.

\section{Experimental Design}

It was recorded that the water temperature in the natural environment where the test organism was collected varied between 12 and $14^{\circ} \mathrm{C}$ throughout the year. In the study, experimental temperatures were chosen as 10,14 , and $18{ }^{\circ} \mathrm{C}$ to prevent the test organism from adapting to laboratory conditions.

In this study, the test organisms were adapted for at least 25 days for each determined temperature. To minimize systematic errors, healthy, similar-sized (w: $0.0474 \pm 0.0053 \mathrm{~g}$ and $\mathrm{L}: 10.35 \pm 0.055 \mathrm{~mm}$ ) and male organisms were selected.

\section{Exposure of G. pulex to Sublethal Cd Concentrations}

Sublethal concentrations in this study were chosen from $\mathrm{Cd}$ concentrations of 1/40, 1/20, and $1 / 10$ ratios of LC50 values for each temperature. For this purpose, four different experimental groups, one of which is the control group, were created. These experimental groups created as follows are applied for each temperature experiment; 
1. Group $\mathrm{C} 0$, control group, $\mathrm{Cd}$-free

2. Group C1, 1/40 LC50 values of Cd

3. Group C2, 1/20 LC50 values of Cd

4. Group C3, 1/10 LC50 values of Cd

In the experimental design, glass aquariums and containing $0.5 \mathrm{~L} \mathrm{Cd}$ concentrations were used. 15 test organisms were added to the aquariums for each group. Test organisms were exposed to three different $\mathrm{Cd}$ concentrations for 96 hours for each temperature group. All experimental procedures were performed in three replicates. Test organisms were not fed in all experimental procedures, including Cd toxicity tests.

\section{Preparation of Homogenates}

The G. pulex specimens for the preparation of homogenates were passed through pure water. A pool was created from 15 individuals to be able to form homogenates from the samples. After the water was removed with the drying paper, organisms were weighed and homogenized by diluting $1 / 10$ in $1.15 \%$ potassium chloride $(\mathrm{KCl})$. The obtained homogenates were centrifuged at $+4{ }^{\circ} \mathrm{C}$ for 15 minutes at $3200 \mathrm{rpm}$ in a glass tube, after which the supernatants were separated.

\section{Biochemical Analyses}

Changes in the MDA levels were measured spectrophotometrically according to Placer et al. (1966) the modified method. The CAT activity was determined according to Aebi (1984). The determination of the GPx activity was made according to the method described by Beutler (1975). Protein quantities were determined according to Lowry et al. (1951) to calculate specific enzyme activities and MDA levels.

Biochemical analyzes have shown changes in oxidant/antioxidant parameters were evaluated by Two Way-ANOVA variance analysis.

\section{Results}

\section{The MDA Level}

The changes in MDA level of control and experimental groups in G. pulex which exposed to sublethal $\mathrm{Cd}$ concentrations were given in Table 1.

When the MDA level at $10^{\circ} \mathrm{C}$ was examined, $\mathrm{C} 3$ group was higher than the control and the difference between them was statistically significant $(p<0.05)$. The MDA levels at $14{ }^{\circ} \mathrm{C}$ were found to be higher in $\mathrm{C} 1, \mathrm{C} 2$, and $\mathrm{C} 3$ groups compared to the control, but the difference between them was statistically insignificant $(\mathrm{p}>0.05)$. The MDA levels at $18^{\circ} \mathrm{C}$ were found to be higher in $\mathrm{C} 1, \mathrm{C} 2$, and $\mathrm{C} 3$ groups compared to the control and the difference between them was statistically $(\mathrm{p}<0.05)$.

Belong to temperature the changes in MDA levels of control and experimental groups in G. pulex which exposed to sublethal $\mathrm{Cd}$ concentrations were given in Table 1.

When the MDA levels at 10,14 , and $18{ }^{\circ} \mathrm{C}$ temperatures of control group samples were examined, the MDA level of the group $14{ }^{\circ} \mathrm{C}$ was higher than at 10 and $18{ }^{\circ} \mathrm{C}$ and the difference between them was statistically significant $(\mathrm{p}<0.05)$.

When the MDA levels at 10,14 , and $18{ }^{\circ} \mathrm{C}$ temperatures of the $\mathrm{C} 1$ group samples were examined, the MDA level of group $10{ }^{\circ} \mathrm{C}$ was lower than the other groups and between differences were found to be significant $(\mathrm{p}<0.05)$.

When the MDA levels at 10,14 , and $18{ }^{\circ} \mathrm{C}$ temperatures of $\mathrm{C} 2$ group samples were examined, MDA level at $18{ }^{\circ} \mathrm{C}$ was found to be statistically higher than $10^{\circ} \mathrm{C}$ temperature $(\mathrm{p}<0.05)$. The MDA level at $14{ }^{\circ} \mathrm{C}$ was found to be similar to the temperature values of 10 and $18{ }^{\circ} \mathrm{C}(\mathrm{p}>0.05)$.

When the MDA levels of $\mathrm{C} 3$ group samples were examined at 10,14 , and $18^{\circ} \mathrm{C}$ temperature, the MDA level determined at all temperatures was not been shown any statistically significant difference $(\mathrm{p}>0.05)$.

Table 1. Changes in MDA levels at different Cd concentrations depending on temperature

\begin{tabular}{lllll}
\hline & \multicolumn{3}{l}{ Control } & \multicolumn{3}{l}{ Sublethal Cd Concentration Groups } \\
\cline { 2 - 5 } Temperature $\left({ }^{\circ} \mathrm{C}\right)$ & $\mathrm{C} 0$ & $\mathrm{C} 1$ & $\mathrm{C} 2$ & $\mathrm{C} 3$ \\
\cline { 2 - 5 } 10 & $1.03 \pm 0.4^{\mathrm{bcY}}$ & $0.75 \pm 0.3^{\mathrm{cY}}$ & $1.41 \pm 0.4^{\mathrm{abY}}$ & $1.85 \pm 0.7^{\mathrm{aX}}$ \\
14 & $1.93 \pm 0.6^{\mathrm{aX}}$ & $1.86 \pm 1.0^{\mathrm{aX}}$ & $1.81 \pm 1.7^{\mathrm{aXY}}$ & $2.13 \pm 1.7^{\mathrm{aX}}$ \\
18 & $0.90 \pm 0.3^{\mathrm{cY}}$ & $2.02 \pm 1.0^{\mathrm{bX}}$ & $2.71 \pm 0.2^{\mathrm{aX}}$ & $3.15 \pm 1.0^{\mathrm{aX}}$ \\
\hline
\end{tabular}

a, b, c: The difference between the values of different letters in the same row was statistically significant $(\mathrm{p}<0.05)$.

$\mathrm{X}, \mathrm{Y}$ : The difference between the values carrying different letters in the same column was statistically significant $(\mathrm{p}<0.05)$.

\section{The GPx Activity}

The changes in the GPx the control and experimental
G. pulex which activity of $\mathrm{Cd}$ concentrations groups in Table 2. 
The GPx activity at $10{ }^{\circ} \mathrm{C}$ was higher in the $\mathrm{C} 1$, $\mathrm{C} 2$, and $\mathrm{C} 3$ groups than Control, and the difference between them was statistically significant $(\mathrm{p}<0.05)$. The GPx activity at $14{ }^{\circ} \mathrm{C}$ was higher in the Control and $\mathrm{C} 2$ groups than $\mathrm{C} 3$ and $\mathrm{C} 1$ groups and the difference between them were statistically significant $(\mathrm{p}<0.05)$. The GPx activity at $18^{\circ} \mathrm{C}$ was higher in the $\mathrm{C} 1, \mathrm{C} 2$, and $\mathrm{C} 3$ groups than in the control group, and the difference between them was statistically significant $(\mathrm{p}<0.05)$.

Belong to temperature the changes in GPx activity in the $\mathrm{C} 0, \mathrm{C} 1, \mathrm{C} 2$, and $\mathrm{C} 3$ groups of $G$. pulex which were exposed to sublethal $\mathrm{Cd}$ concentrations were given in Table 2.

When the GPx activity of the control group was examined at 10,14 , and $18^{\circ} \mathrm{C}$ temperatures, the GPx activity was the highest at $10{ }^{\circ} \mathrm{C}$ and the lowest at 18 ${ }^{\circ} \mathrm{C}$, and the difference between groups was statistically significant $(\mathrm{p}<0.05)$.

When the GPx activity of the $\mathrm{C} 1$ group was examined at 10,14 , and $18^{\circ} \mathrm{C}$. The GPx activity was the highest in the $\mathrm{C} 1$ group. Between them, the difference was statistically significant $(p<0.05)$.

When the GPx activity of the $\mathrm{C} 2$ group, at temperatures of 10,14 , and $18{ }^{\circ} \mathrm{C}$ was examined in the GPx activity was the highest at $10{ }^{\circ} \mathrm{C}$ and the lowest at $18{ }^{\circ} \mathrm{C}$ and the difference between groups was statistically significant $(\mathrm{p}<0.05)$.

When the GPx activity of the C3 group at temperatures of 10,14 , and $18^{\circ} \mathrm{C}$ was examined GPx activity was lowest at $18{ }^{\circ} \mathrm{C}$. Between them, the difference was statistically significant $(\mathrm{p}<0.05)$.

Table 2. The GPx activity changes in Cd concentrations depending on temperature

\begin{tabular}{|c|c|c|c|c|}
\hline \multirow{2}{*}{$\left({ }^{\circ} \mathrm{C}\right)^{\text {Temperature }}$} & Control & \multicolumn{3}{|c|}{ Sublethal Cd Concentration Groups } \\
\hline & $\mathrm{C}_{0}$ & $\mathrm{C}_{1}$ & $\mathrm{C}_{2}$ & $\mathrm{C}_{3}$ \\
\hline 10 & $24.54 \pm 0.4^{\mathrm{aX}}$ & $7.29 \pm 0.2^{\mathrm{dY}}$ & $19.67 \pm 0.7^{\mathrm{cX}}$ & $20.88 \pm 1.6^{\mathrm{bX}}$ \\
\hline 14 & $17.03 \pm 0.2^{b Y}$ & $20.33 \pm 0.9^{\mathrm{aX}}$ & $17.48 \pm 0.9^{\mathrm{bY}}$ & $19.67 \pm 0.7^{\mathrm{aX}}$ \\
\hline 18 & $3.54 \pm 0.8 \mathrm{cZ}$ & $7.15 \pm 0.8^{b Y}$ & $11.64 \pm 2.8^{\mathrm{aZ}}$ & $13.18 \pm 0.3^{\mathrm{aY}}$ \\
\hline
\end{tabular}

a, b, c, d: The difference between the values of different letters in the same row was statistically significant $(\mathrm{p}<0.05)$.

$\mathrm{X}, \mathrm{Y}, \mathrm{Z}$ : The difference between the values carrying different letters in the same column was statistically significant $(\mathrm{p}<0.05)$.

\section{The CAT Enzyme Activity}

The changes in the CAT activity of the control and experimental groups in the G. pulex organisms exposed to sublethal $\mathrm{Cd}$ concentrations were given in Table 3.

When the CAT activity at $10 \quad{ }^{\circ} \mathrm{C}$ was examined, $\mathrm{C} 2$, and $\mathrm{C} 3$ groups it was found to be statistically higher than the control group $(\mathrm{p}<0.05)$. When the CAT activity at $14{ }^{\circ} \mathrm{C}$ was examined, the $\mathrm{C} 1$ group was found statistically higher than the other groups $(\mathrm{p}<0.05)$. When the CAT activity at $18{ }^{\circ} \mathrm{C}$ was examined, $\mathrm{C} 2$ and $\mathrm{C} 3$ groups were higher than the control group and the difference between them was found statistically significant $(\mathrm{p}<0.05)$.

Belong to temperature the changes in CAT activity of control and experimental groups in $G$. pulex which exposed to sublethal $\mathrm{Cd}$ concentrations were given in Table 3.
When the CAT activities of the control group were examined at 10,14 , and $18^{\circ} \mathrm{C}$ temperatures, the CAT activity was higher at $14{ }^{\circ} \mathrm{C}$ and the lowest at $18^{\circ} \mathrm{C}$ temperature, and the difference between groups was statistically significant $(\mathrm{p}<0.05)$.

When the CAT activities of the $\mathrm{C} 1$ groupwere examined at 10,14 , and $18^{\circ} \mathrm{C}$ temperatures, the CAT activity was higher at $14{ }^{\circ} \mathrm{C}$ and the lowest at $18{ }^{\circ} \mathrm{C}$ temperature, and the difference between groups was statistically significant $(\mathrm{p}<0.05)$.

When the CAT activities of the $\mathrm{C} 2$ group were examined at 10,14 , and $18^{\circ} \mathrm{C}$ temperatures, the CAT activity was the highest at $10{ }^{\circ} \mathrm{C}$ and the lowest at $18{ }^{\circ} \mathrm{C}$, and the difference between groups was statistically significant $(\mathrm{p}<0.05)$.

When the CAT activities of the $\mathrm{C} 3$ group were examined at 10,14 , and $18{ }^{\circ} \mathrm{C}$ temperatures, the CAT activity was the highest at $10{ }^{\circ} \mathrm{C}$ and the lowest at $18{ }^{\circ} \mathrm{C}$, and the difference between groups was statistically significant $(\mathrm{p}<0.05)$.

Table 3. The CAT activity changes in Cd concentrations depending on temperature

\begin{tabular}{|c|c|c|c|c|}
\hline \multirow{2}{*}{ Temperature $\left({ }^{\circ} \mathrm{C}\right)$} & Control & \multicolumn{3}{|c|}{ Sublethal Cd Concentration Groups } \\
\hline & $\mathrm{C}_{0}$ & $\mathrm{C}_{1}$ & $\mathrm{C}_{2}$ & $\mathrm{C}_{3}$ \\
\hline 10 & $64.40 \pm 40.4^{\mathrm{bY}}$ & $76.91 \pm 60.7^{\mathrm{bY}}$ & $159.66 \pm 66.6^{\mathrm{aX}}$ & $179.94 \pm 78.8^{\mathrm{aX}}$ \\
\hline 14 & $82.16 \pm 33.7^{b X}$ & $157.02 \pm 13.1^{\mathrm{aX}}$ & $103.42 \pm 39.0^{b Y}$ & $108.32 \pm 32.7^{b X}$ \\
\hline 18 & $4.86 \pm 1.8^{\mathrm{cZ}}$ & $9.20 \pm 2.5^{c Z}$ & $28.29 \pm 3.6^{\mathrm{bZ}}$ & $45.32 \pm 17.6^{\mathrm{aY}}$ \\
\hline
\end{tabular}

$\mathrm{a}, \mathrm{b}, \mathrm{c}$ : The difference between the values of different letters in the same row was statistically significant $(\mathrm{p}<0.05)$.

$\mathrm{X}, \mathrm{Y}, \mathrm{Z}$ : The difference between the values carrying different letters in the same column was statistically significant $(\mathrm{p}<0.05)$. 


\section{Discussion}

Toxicology examines the damage and destructive effects of physical or chemical agents on living organisms. In this context, aquatic toxicology tests aim to determine at what concentration any substance harms organisms on aquatic organisms (Karataş 2005).

Bat et al. (2000) determined the LC50 values of zinc $(\mathrm{Zn})$, copper $(\mathrm{Cu})$, and lead $(\mathrm{Pb})$ toxicity in freshwater amphipods at G. pulex at three different temperatures $\left(15,20\right.$, and $\left.25^{\circ} \mathrm{C}\right)$. They reported that LC50 values were decreased with temperature. Zauke (1982) investigated the relationship between Cd's acute toxicity to seasonal variation and environmental variables in Gammarus tigrinus natural populations and reported that there is a relationship between $\mathrm{Cd}$ concentration and water temperature. Piazza et al. (2016), conducted a study to evaluate the nature of the toxicity test in the study, in particular, the temperature and salinity changes in the presence of a toxic substance, and the environmental impact of information on the role of these parameters. Changes in temperature and salinity were observed separately, regardless of whether reference toxic substances were present, to obtain initial information on the final test results. As a result, they reported that temperature and salinity were effective in organisms. Qiu and Qian (1999), were indicated that Amphitrite amphitrite at the larval stage is significantly affected by temperature, as well as markedly by both survival and development. Nasrolahi et al. (2013), showed that model organisms' low temperature and low salinity stress affect larval growth after 7 and 40 days and that these environmental changes can directly affect.

In the aquatic environment, pollution can cause toxic effects such as lipid peroxidation by increasing ROS production resulting from the imbalance between ROS concentration and antioxidant defense system (Regoli et al. 2004). Key antioxidant enzymes and non-enzymatic antioxidants are influenced by various single pollutants known to increase ROS levels (Valko et al. 2006; Ryter et al. 2007). Oxidative stress, detoxification, and neurotoxicity biomarkers were used in Gammarids (Yildirim et al. 2019).

Lipid peroxidation, considered as a valuable indicator of oxidative damage of cellular components known as the first step in cellular membrane damage, is caused by pesticides, metals, and other xenobiotics (Gamble et al. 1995; Regoli et al. 1998). Duman and Kar (2015) reported that the MDA content of Cd accumulation in organisms increased depending on the exposure concentration and duration. Similarly, in this study, the MDA levels were also increased in sublethal Cd concentration groups when compared to the control group $(\mathrm{p}<0.05)$. Chandran et al. (2005) investigated how to change the MDA levels of $\mathrm{Cd}$ and $\mathrm{Zn}$ in Achatina fulica. They reported that the MDA levels increased with increasing $\mathrm{Cd}$ concentration compared to the study data. In this study, the MDA levels increased with the concentration of $\mathrm{Cd}$, and the data of the study showed parallelism.

Vellinger et al. (2013) found that the MDA levels in G. pulex, where $\mathrm{Cd}$ and arsenic (As) were single and co-administered, were higher than the control group. They also reported a significant increase (67.2\%) in the MDA levels with increasing $\mathrm{Cd}$ concentration in the individuals. In this study, it was found that the MDA levels increased due to both temperature and concentration increase. Sroda and Cossu-Leguille (2011) investigated the effect of seasonal changes on antioxidant markers in Gammarus roeselli. In parallel with the increase in temperature, the model reported the increase of MDA level in living organisms. In this study, MDA levels increased with temperature.

The GPx is a component of a complex antioxidant defense system and its response is possibly accompanied by responses of other antioxidant enzymes and scavenger molecules; however, its induction may provide an indication of defense against oxidative stress (Tsangaris et al. 2007). Inhibition of the GPx activity may reflect the failure of the antioxidant system in contact with polluting (Ballesteros et al. 2009) or may be related to the direct effect of superoxide radicals or pollutes on enzyme synthesis (Bainy et al. 1993). In this study, GPx activity in G. pulex exposed to $\mathrm{Cd}$ decreased at $10{ }^{\circ} \mathrm{C}$ compared to the control group. As well as GPx activity decreased with the temperature of exposure to $\mathrm{Cd}$ in the G. pulex organism ( $\mathrm{p}<0.05$ ). In this study, GPx activity decreased with increasing temperature of exposure to $\mathrm{Cd}$ in G. pulex organism (p <0.05). Depending on the temperature, the reduction of observed GPx activities may be associated with decreased glutathione levels. This decrease in GPx activity in the study is in line with the studies performed (Serdar et al. 2019b; Kutlu and Susuz 2004). However, in another study, CAT activity increased with $\mathrm{Cd}$ exposure and this increase suppressed the increase in GPx (Zhang et al. 2011). The reason for the increase in GPx activity at 14 and $18{ }^{\circ} \mathrm{C}$ temperatures in this study can be explained by the decrease in CAT activity.

The CAT is a very common enzyme found in virtually all living organisms that use oxygen. It acts in water and oxygen formation by catalyzing the decomposition of hydrogen peroxide (Chelikani et al. 2004). The elevation of these antioxidant enzymes would be critical in minimizing cellular injury 
(Rajeshkumar et al. 2013). On the other hand, CAT activity may increase or decrease in contaminated environments depending on the substance (Sobjak et al. 2017). In previous studies, it had been expressed that ROS species can inhibit CAT activity (Kono and Fridovich 1982; Escobar et al. 1996; Duman and Kar 2015). In this study, while CAT activity decreased due to increasing temperature but increased due to increased concentration (Table 3) $(\mathrm{p}<0.05)$. Antioxidative stress activity can change depending on sexuality, physiological phase, and species (Felten et al. 2008; Zhang et al. 2011). However, it was found that $\mathrm{Cd}$ exposure concentration and exposure duration can also alter antioxidative stress activity (Duman and Kar 2015). They further revealed that short-term exposure to organic chemical pollutants leads to the induction of antioxidant enzymes in aquatic organisms. However, CAT activity was negatively affected by redox-cycling-inducing chemicals (Pandey et al 2008; Rajeshkumar et al. 2013). In this study, the CAT enzyme activity is inhibited by the organisms under stress with temperature and $\mathrm{Cd}$ exposure. Similar to the present study, decrease in CAT activity have been reported in aquatic organisms exposed to various pollutants (Thomas and Murthy 1976; Hasspieler et al. 1994; Sayeed et al. 2003; Zhang et al. 2004; Crestani et al. 2007; Yildirim et al. 2018). According to the results found in the literature related to the activity of this enzyme, potential antioxidant changes by species, habitat, etc. can be explained (Glusczak et al. 2007).

Many factors that cause chemical pollution arising from various industrial activities, which accumulated in living organisms, can be transported in ecosystems from the lowest of the food chain to in the top ring chain of the food chain.

Physiological factors, such as temperature and salinity, can be an important factor in ecotoxicological analyses when exposed to the stressors of organisms (Piazza et al. 2016).

In this study, it was determined the oxidative response of exposure to at different temperature sublethal $\mathrm{Cd}$ concentrations of G. pulex, which is used as a clean water indicator in ecotoxicological evaluations. In this study, it can be concluded that stress conditions provided by $\mathrm{Cd}$ exposure at sublethal concentrations and different temperatures evoked specific responses in G. pulex. Therefore, the above results indicate that $\mathrm{Cd}$ and temperature an environmental pollutants as oxidative stress.

\section{Acknowledgments}

This study was supported by the Scientific Research Project Coordination Unit of Munzur University under project number DRTUB015-01.

\section{References}

Achary VMM, Jena S, Panda KK, Panda BB. 2008. Aluminium induced oxidative stress and DNA damage in root cells of Allium cepa. L. Ecotox Environ Safe. 70(2):300-310.

doi: 10.1016/j.ecoenv.2007.10.022

Aebi H. 1984. Catalase in vitro. Method Enzymol. 105:121-126.

doi: 10.1016/S0076-6879(84)05016-3

Almroth BC, Albertsson E, Sturve J, Förlin L. 2008. Oxidative stress, evident in antioxidant defences and damage products, in rainbow trout caged outside a sewage treatment plant. Ecotox Environ Safe. 70(3):370-378.

doi: 10.1016/j.ecoenv.2008.01.023

Asri FÖ, Sönmez S, Çıtak S. 2007. Kadmiyumun çevre ve insan sağlığ 1 üzerine etkileri. Derim. 24(1):32-39.

Bainy ACD, Arisi ACM, Azzalis LA, Simizu K, Barros SBM, Videla LA, Junqueira VBC. 1993. Differential effects of short- term lindane administration on parameters related to oxidative stress in rat liver and erythrocytes. J Biochem Toxicol. 8(4):187-194. doi: $10.1002 /$ jbt.2570080404

Ballesteros ML, Wunderlin DA, Bistoni MA. 2009. Oxidative stress responses in different organs of Jenynsia multidentata exposed to endosulfan. Ecotox Environ Safe. 72(1):199-205. doi: 10.1016/j.ecoenv.2008.01.008

Bat L, Akbulut M, Çulha M, Gündoğdu A, Satılmış HH. 2000. Effect of temperature on the toxicity of zinc, copper and lead to the freshwater amphipod Gammarus pulex pulex (L., 1758). Turkish Journal of Zoology. 24(4):409-416.

Bertin G, Averbeck D. 2006. Cadmium: cellular effects, modifications of biomolecules, modulation of DNA repair and genotoxic consequences (a review). Biochimie. 88(11):1549-1559.

doi: 10.1016/j.biochi.2006.10.001

Beutler E. 1975. Red cell metabolism, a manual of biochemical methods. Grune Strottan, New York.

Brzóska MM, Moniuszko-Jakoniuk J. 2001. Interactions between cadmium and zinc in the organism. Food Chem Toxicol. 39(10):967-980. doi: 10.1016/S0278-6915(01)00048-5

Chandran R, Sivakumar AA, Mohandass S, Aruchami M. 2005. Effect of cadmium and zinc on antioxidant enzyme activity in the gastropod, Achatina fulica. Comp Biochem Phys C. 140(3-4):422-426. doi: 10.1016/j.cca.2005.04.007

Chelikani P, Fita I, Loewen PC. 2004. Diversity of structures and properties among catalases. Cell Mol Life Sci. 61(2):192-208.

doi: 10.1007/s00018-003-3206-5

Cimen ICC, Danabas D, Ates M. 2020. Comparative effects of $\mathrm{Cu}(60-80 \mathrm{~nm})$ and $\mathrm{CuO}(40 \mathrm{~nm})$ nanoparticles in Artemia salina: Accumulation, elimination and oxidative stress. Sci Total Environ. 717:137230-137240. doi: 10.1016/j.scitotenv.2020.137230

Crestani M, Menezes C, Glusczak L, dos Santos Miron D, Spanevello R, Silveira A, Gonçalves FF, Zanella R, 
Loro VL. 2007. Effect of clomazone herbicide on biochemical and histological aspects of silver catfish (Rhamdia quelen) and recovery pattern. Chemosphere. 67(11):2305-2311.

doi: 10.1016/j.chemosphere.2006.09.070

Dat J, Vandenabeele S, Vranová E, Van Montagu M, Inzé D, Van Breusegem F. 2000. Dual action of the active oxygen species during plant stress responses. Cell Mol Life Sci. 57:779-795. doi: 10.1007/s000180050041

Del Valls TA, Blasco J, Sarasquete MC, Forja JM, GómezParra A. 1998. Evaluation of heavy metal sediment toxicity in littoral ecosystems using juveniles of the fish Sparus aurata. Ecotox Environ Safe. 41(2): 157-167.

doi: 10.1006/eesa.1998.1680

Duffus, J. H. 1980. Environmental Toxicology. Edward Arnold (Publishers) Ltd. London.

Duman F, Kar M. 2015. Evaluation of effects of exposure conditions on the biological responses of Gammarus pulex exposed to cadmium. Int $\mathbf{J}$ Environ Sci Te. $12: 437-444$.

doi: 10.1007/s13762-013-0425-7

Escobar JA, Rubio MA, Lissi EA. 1996. SOD and catalase inactivation by singlet oxygen and peroxyl radicals. Free Radical Bio Med. 20(3):285-290. doi: 10.1016/0891-5849(95)02037-3

Felten V, Charmantier G, Mons R, Geffard A, Rousselle P, Coquery M, Garric J, Geffard O. 2008. Physiological and behavioural responses of Gammarus pulex (Crustacea: Amphipoda) exposed to cadmium. Aquat Toxicol. 86 (3) :413-425. doi: 10.1016/j.aquatox.2007.12.002

Gamble SC, Goldfarb PS, Porte C, Livingstone DR. 1995. Glutathione peroxidase and other antioxidant enzyme function in marine invertebrates (Mytilus edulis, Pecten maximus, Carcinus maenas and Asterias rubens). Mar Environ Res. 39 (1-4): 191-195. doi: 10.1016/0141-1136(94)00031-J

Glusczak L, dos Santos Miron D, Moraes BS, Simões RR, Schetinger MRC, Morsch VM, Loro VL. 2007. Acute effects of glyphosate herbicide on metabolic and enzymatic parameters of silver catfish (Rhamdia quelen). Comp Biochem Phys C. 146(4):519-524. doi: 10.1016/j.cbpc.2007.06.004

Halliwell B, Gutteridge JMC. 2007. Free radicals in biology and medicine. New York: Oxford University Press $851 \mathrm{p}$.

Hasspieler BM, Behar JV, Carlson DB, Watson DE, Di Giulio RT. 1994. Susceptibility of channel catfish (Ictalurus punctatus) and brown bullhead (Ameriurus nebulosus) to oxidative stress: a comparative study. Aquat Toxicol. 28(1-2):53-64. doi: 10.1016/0166-445X(94)90020-5

Hermes-Lima M. 2004. Oxygen in biology and biochemistry: Role of free radicals. In: Storey KB, editor. Functional metabolism: regulation and adaptation. USA: John Wiley \& Sons, Inc. p. 319-368.

Hu H. 2000. Exposure to metals. Primary care: clinics in office practice. 27(4):983-996. doi: 10.1016/S0095-4543(05)70185-8

Jemec A, Tisler T, Erjavec B, Pintar A. 2012. Antioxidant responses and whole-organism changes in Daphnia magna acutely and chronically exposed to endocrine disruptor bisphenol A. Ecotox Environ Safe. 86: 213218. doi: 10.1016/j.ecoenv.2012.09.016

Karataş M. 2005. Balık biyolojisi araştırma yöntemleri. Ankara: Nobel Yayınları 498 p. [in Turkish]

Katalay S, Parlak H. 2002. Su Kirliliğinin, Gobius niger Linn., 1758 (Pisces: Gobiidae)'in Kan Parametreleri Üzerine Etkileri. Ege University Journal of Fisheries and Aquatic Sciences. 19(1-2):115-121.

Kayhan FE. 2006. Su Ürünlerinde Kadmiyumun Biyobirikimi ve Toksisitesi. Ege University Journal of Fisheries and Aquatic Sciences. 23(1-2):215-220.

Kono Y, Fridovich I. 1982. Inhibition of catalase by superoxide radicals. . J Biol Chem. 257:5751-5754.

Kutlu M, Susuz F. 2004. Effects of lead as an environmental pollutant on EROD enzyme in Gammarus pulex (L.) (Crustacea: Amphipoda). B Environ Contam Tox. 72(4): 750-755. doi: 10.1007/s00128-001-0308-1

Lowry OH, Rosenberough NJ, Farr AL, Randal RJ. 1951. Protein measurement with folinphenol reagent. J Biol Chem. 193(1):265-275.

Nasrolahi A, Pansch C, Lenz M, Wahl M. 2013.Temperature and salinity interactively impact early juvenile development: a bottle neck in barnacle ontogeny. Mar Biol. 160:1109-1117. doi: 10.1007/s00227-012-2162-8

Pandey S, Parvez S, Ansari RA, Ali M, Kaur M, Hayat F, Ahmad F, Raisuddin S. 2008. Effects of exposure to multiple trace metals on biochemical, histological and ultrastructural features of gills of a freshwater fish, Channa punctata Bloch. Chem-Biol Interact. 174(3):183-192. doi: 10.1016/j.cbi.2008.05.014

Piazza V, Gambardella C, Canepa S, Costa E, Faimali M, Garaventa F. 2016. Temperature and salinity effects on cadmium toxicity on lethal and sublethal responses of Amphibalanus amphitrite nauplii. Ecotox Environ Safe. 123:8-17. doi: 10.1016/j.ecoenv.2015.09.023

Placer ZA, Cushman L, Johnson BC. 1966. Estimation of products of lipid peroxidation (malonyl dialdehyde) in biological systems. Anal Biochem. 16(2):359-364. doi: 10.1016/0003-2697(66)90167-9

Qiu JW, Qian PY. 1999. Tolerance of the barnacle Balanus Amphitrite amphitrite to salinity and temperature stress: effects of previous experience. Mar Ecol Prog Ser. 188:123-132.

Rajeshkumar S, Mini J, Munuswamy N. 2013. Effects of heavy metals on antioxidants and expression of HSP70 in different tissues of Milk fish (Chanos chanos) of Kaattuppalli Island, Chennai, India. Ecotox Environ Safe. 98:8-18. doi: 10.1016/j.ecoenv.2013.07.029

Regoli F, Nigro M, Orlando E. 1998. Lysosomal and antioxidant responses to metals in the Antarctic 
scallop Adamussium colbecki. Aquat

Toxicol. 40(4):375-392.

doi: 10.1016/S0166-445X(97)00059-3

Regoli F, Frenzilli G, Bocchetti R, Annarumma F, ScarcelliV, Fattorini D, Nigro M. 2004. Time-course variations of oxyradical metabolism, DNA integrity and lysosomal stability in mussels, Mytilus galloprovincialis, during a field translocation experiment. Aquat Toxicol. 68(2):167178.

doi: 10.1016/j.aquatox.2004.03.011

Ryter SW, Kim HP, Hoetzel A, Park JW, Nakahira K, Wang X, Choi AM. 2007. Mechanism of cell death in oxidative stress. Antioxid Redox Sign. 9(1):49-89. doi: 10.1089/ars.2007.9.49

Sayeed I, Parvez S, Pandey S, Bin-Hafeez B, Haque R, Raisuddin S. 2003. Oxidative stress biomarkers of exposure to deltamethrin in freshwater fish, Channa punctatus Bloch. Ecotox Environ Safe. 56(2): 295-301. doi: 10.1016/S0147-6513(03)00009-5

Serdar O, Yildirim NC, Tatar S, Yildirim N, Ogedey A. 2018. Antioxidant biomarkers in Gammarus pulex to evaluate the efficiency of electrocoagulation process in landfill leachate treatment. Environ Sci Pollut R. 25(13):12538-12544.

doi: $10.1007 / \mathrm{s} 11356-018-1491-7$

Serdar O. 2019. The effect of dimethoate pesticide on some biochemical biomarkers in Gammarus pulex. Environ Sci Pollut R. 26(21): 21905-21914. doi: 10.1007/s11356-019-04629-w

Serdar O, Aydın R, Çalta M. 2019a. The Evaluation in Different Temperature of Acute Toxic Effect of Cadmium on Gammarus pulex (Freshwater Amphipoda). Journal of Anatolian Environmental and Animal Sciences. 4(3): 366-370. doi: 10.35229/jaes.591384

Serdar O, Yıldırım NC, Tatar Ş, Yıldırım N. 2019 b. Kurşuna Maruz Bırakılan Gammarus pulex'de Antioksidan Enzim Yanitlar1. Journal of Anatolian Environmental and Animal Sciences. 4(2):216-220. doi: 10.35229/jaes.571909

Sobjak TM, Romão S, do Nascimento CZ, dos Santos AFP, Vogel L, Guimarães ATB. 2017. Assessment of the oxidative and neurotoxic effects of glyphosate pesticide on the larvae of Rhamdia quelen fish. Chemosphere. 182:267-275.

doi: 10.1016/j.chemosphere.2017.05.031

Sroda S, Cossu-Leguille C. 2011. Seasonal variability of antioxidant biomarkers and energy reserves in the freshwater gammarid Gammarus roeseli. Chemosphere. 83(4):538-544. doi: 10.1016/j.chemosphere.2010.12.023

Tatar S, Yildirim NC, Serdar O, Yildirim N, Ogedey A. 2018. The using of Gammarus pulex as a biomonitor in ecological risk assessment of secondary effluent from municipal wastewater treatment plant in Tunceli, Turkey. Hum Ecol Risk Assess. 24(3):819-829. doi: 10.1080/10807039.2017.1400374
Taylan ZS, Özkoç HB. 2007. Potansiyel ağır metal kirliliğinin belirlenmesinde akuatik organizmaların biokullanılabilirliliği. Balıkesir Üniversitesi Fen Bilimleri Enstitüsü Dergisi. 9(2):17-33.

Thomas PC, Murthy TL. 1976. Studies on the impact of a few organic pesticides on certain fish enzymes. Indian J Anim Sci. 46(11):619-624.

Tsangaris C, Papathanasiou E, Cotou E. 2007. Assessment of the impact of heavy metal pollution from a ferronickel smelting plant using biomarkers. Ecotox Environ Safe. 66(2):232-243. doi: 10.1016/j.ecoenv.2006.03.011

Valko M, Rhodes CJ, Moncol J, Izakovic M, Mazur M. 2006. Free radicals, metals and antioxidants in oxidative stress induced cancer. Chem-Biol Interact. 160(1):1-40. doi: 10.1016/j.cbi.2005.12.009

Vellinger C, Gismondi E, Felten V, Rousselle P, Mehennaoui K, Parant M, Usseglio-Polatera P. 2013. Single and combined effects of cadmium and arsenate in Gammarus pulex (Crustacea, Amphipoda): understanding the links between physiological and behavioural responses. Aquat Toxicol. 140-141: 106116. doi: 10.1016/j.aquatox.2013.05.010

Waisberg M, Joseph P, Hale B, Beyersmann D. 2003. Molecular and cellular mechanisms of cadmium carcinogenesis. Toxicology. 192(2-3):95-117. doi: 10.1016/S0300-483X(03)00305-6

Yildirim NC, Tanyol M, Yildirim N, Serdar O, Tatar S. 2018. Biochemical responses of Gammarus pulex to malachite green solutions decolorized by Coriolus versicolor as a biosorbent under batch adsorption conditions optim ized with response surface methodology. Ecotox Environ Safe. 156:4147.

doi: 10.1016/j.ecoenv.2018.02.059

Yildirim NC, Tanyol M, Serdar O, Yildirim N. 2019. Gammarus pulex as a model organism to assess the residual toxicity of slaughterhouse wastewater treated by electrocoagulation process. B Environ Contam Tox. 103(3):447-452. doi: 10.1007/s00128-019-02666-2

Zauke GP. 1982. Cadmium in Gammaridae (Amphipoda: Crustacea) of the rivers Werra and Weser-II: Seasonal variation and correlation to temperature and other environmental variables. Water Res. 16(6): 785-792. doi: 10.1016/0043-1354(82)90005-7

Zhang J, Shen H, Wang X, Wu J, Xue Y. 2004. Effects of chronic exposure of 2, 4-dichlorophenol on the antioxidant system in liver of freshwater fish Carassius auratus. Chemosphere. 55(2):167-174. doi: 10.1016/j.chemosphere.2003.10.048

Zhang Y, Sun G, Yang M, Wu H, Zhang J, Song S, Ma E, Guo Y. 2011. Chronic accumulation of cadmium and its effects on antioxidant enzymes and malondialdehyde in Oxya chinensis (Orthoptera: Acridoidea). Ecotox Environ Safe. 74(5):1355-1362. doi: 10.1016/j.ecoenv.2011.03.002 